13) J. Rechnev: Ind. Eng. Chem., 36, 118 (1944)

14) T. S. Lee, I. M. Kolthoff, M. A. Mairs: J. Polymer Sci., 3, 66 (1948)

15) G. A. Blokh: Rubber Chem. Technol., 32, 628 (1959)

16）水渡英二，荒川正文：ゴム協，34，894（1961）

17) H. L. Dinsmore, D. C. Smith: Anal. Chem., 20, 11 (1948)

18）田中誠之, 川端欣五, 二㧚好正, 鎌田 仁：工化, 66, 1571 (1963)

19) R. L. Harris, G. R. Svobada: Anal. Chem., 34, 1655 (1962)
20）小林揵次，松尾 博：日本化学会第18年会(1965)

21）由中誠之：Jasco Report, 2, No. 3, 1 (1965)

22) R. R. Hampton: Anal. Chem., 21, 923 (1949)

23) J. L. Binder: Anal. Chem., 26, 1877 (1954); J. Polymer Sci., A 1, 47 (1963)

24) R. S. Silas, J. Yates, V. Thornton: Anal. Chem., 31, 529 (1959)

25) D. Morero, A. Santambrogio, Porri, F. Clampell: Chim. e. Ind., 41, 758 (1959)

26）大垑齊之助, 田中康之, 吉本敏雄, 藤森 惊: 高 分子, 13, 252 (1964)

\title{
Quantitative Analysis of Microstructure of Rubber
}

I. Analysis of cis-, trans-, and vinyl-structures of Unvulcanized Rubber Blend by Using the Attenuated Total Reflection Spectrometer

By Junnosuke Hayashi, ${ }^{*}$ Junji Furukawa** and Shinzo Yamashita**

\begin{abstract}
Quantitative analysis of the microstructure of cis-polybutadiene blended with emulsion polybutadiene was carried out by using the Attenuated Total Reflection Spectrometer (ATR). The angle change of the incidence to the surface of cis-polybutadiene was investigated to clarify an optimum angle for detection of cis-, trans-, and vinyl-structures. Apparent concentration of each structure was calculated by using the modified equation of Morero, and was compared to the concentration determined from usual transmission IR method to afford a calibration curve.

As the result, ATR method was found to be suitable for a quantitative analysis of the microstructure in polybutadiene or polybutadiene blend. Moreover, it is expectable that this method is able to apply to an analysis of the microstructure in polybutadiene vulcanizate.
\end{abstract}

第 2 報 加硫中におけるシスーポリブタジエンのミクロ構造の変化

(1966年 3 月 8 日受理)

林 順之助***. 古川淳二**** · 山下晋三****

\begin{abstract}
要 旨 シスーポリブタジェンの加硫中におけるシスートランス異性化ならびに二重結合㟵度の変 化を, 赤外全反射吸収スベクトル法（AＴR 法）により定量を行なった。加硫度を変化させたイオ

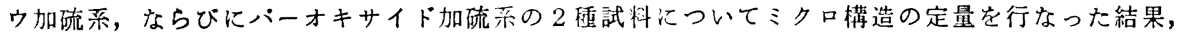
シス構造がトランス構造に唭性化することを認めた。さらにパーオキサイジ采加硫ゴムではオオ 加硫采に比べて橋かけの進行とともにシス濃度, および全二重結合濃度の減少が大きく, 反応した バーオキサイドに対して10倍以上の橋かけ浱度に達することがわかり, 㭼かけ反応は二重結合に対 するラジカル付加の連銷反応で進行することを地めた。
\end{abstract}

\footnotetext{
* Central Research Institute, Ube Industries, Ltd. (Ube, Yamaguchi)

** Department of Synthetic Chemistry, Faculy of Engineering, Kyoto University (Yoshida, Sakyo-ku, Kyoto)

*** 宇部興産䏭式会社中央研究所 (山口県字部市大字小串)

**** 京都大学工学部合成化学教室(京都市左京区吉田本町)
} 


\section{1. 緒言}

加硫ゴムの構造はゴムの種類,加硫系により異なるが， ジエン系ゴムについて考兑られる代表的なものは次のを おりである。<smiles>CC#CC(C)[SiH2]C(C)C=CC</smiles>

$$
\text { イオウ加硫 }
$$<smiles>CCC(C)[SiH2]C(CC)CC</smiles><smiles>C1CCSC1</smiles>

(I) 置換型

（II）付加型 (III) 分子内橋かけ型 ペーオキサイド加硫

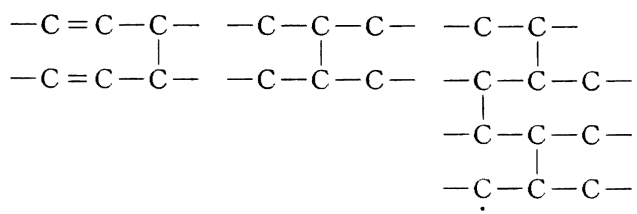
(IV) 置換型
(V) 付加型
(VI) 連鎖型

イオウ加硫系では $\alpha$ メチレン基の水素の置換による 橋かけ（I ），二重結合に対する付加による橋加け（II） の他に 5 員環，また流 6 員環形成による分子内橋かけ （III）などに分類され，実際にはこれらの橋かけ櫵造が組 み合わさった型となっている1) 4)。ハーー才キサイドによ る加硫ではイオウ系と同様の置換型 (IV)，抢よび付加型 (V)の橋かけの他に二重結合に対する付加反応が連鎖的 に進む場合（VI）がある。天然ゴムでは供試ハーオキサ イド当モルの橋かけが生成するのに対し，ポリブタジ エンでは供試パーオキサイド裖度の10倍以上の橋かけが 生成し, 二重結合へのラジカル付加反応が連鎖的に起こ る。これについては膨閵法による橋かけ浱度測定結果か ら報告されている(5),6)。付加反応が連鎖的に進むとそれ だけ二重結合浱度が低下するが，この变化を定量するこ とにより橋かけ構造を推定することが可能である。二重 絬合罣度の定量法は化学的な方法の他に赤外分析によっ ても可能であるが，加硫ゴムについて ATR 法で検討し た银告はない。本報では前報》に続いて ATR 法で加硫 中のミクロ構造の変化の定量を試みた。すなわち,シスー ポリブタジェンについてイオウ加硫系, ならびにパーオ キサイド加硫系で，加硫度を变化させた試料についてミ クロ楧造の変化を定量し, シス, トランス異性化ならび に全二重結合竖度の変化を調べ，橋かけ浱度と比較する ことにより橋かけ構造を検討した。

\section{2. 方法および結果}

\section{1 試料の作成}

シスーポリブタジェンのイオウ加硫系ならびにパーオ キサイド加硫系の 2 種について測定したが, 両系につい ての配合は Table 1 のと护りである。
Table 1. Compounding recipe.

\begin{tabular}{lr|cr}
\hline \multicolumn{1}{r|}{ Sulfur cure } & & \multicolumn{2}{|c}{ Peroxide cure } \\
\hline cis-polybutadiene & 100 & cis-polybutadiene $^{\mathrm{a})}$ & 100 \\
ZnO & 5 & Dicumyl-peroxided $^{\mathrm{d}}$ & 2 \\
Stearic acid & 2 & & \\
Sulfur & 1.5 & & \\
CZ $^{\text {b) }}$ & 1.0 & & \\
TMTD $^{c)}$ & 0.2 & & \\
\hline
\end{tabular}

a) Ameripol CB, b) Cyclohexyl-benzothiazyl-sulfenamide, c) Tetramethyl-thiuram disulfide, d) Purity $97 \%$

$300 \mathrm{~g}$ のゴムを常温で 6 インチオープンロールを用い， 30 回薄通しすることにより Table 1 に示した配合戍を 混合し， $150^{\circ} \mathrm{C}$ でプレス加硫を行なった。加硫度による ミクロ構造の変化を知るために，加硫時間を10分から 90 分まで変化させた。プレス加硫て得られた厚さ約 $2 \mathrm{~mm}$ の試料について, 網目間鎖数濃度を求めるた膨澗実験 および応力ーひずみ曲線の測定を行ない,さらにATR 法 で加硫ゴムのミクロ構造を調べた。

\section{2 ミク口構造の測定法}

ミクロ構造の变化は前報の ATR 法に従って測定し た。すなわ台，日本分光製 $\mathrm{KBr}$ 型 IR-S を用い，全反射 ブリズムとして KRS-6 を使った ATR 装置をせットし 補傥光路側の減光率 $35 \%$, 入射角 $49^{\circ}$, チャートスヒ ート $50 \mathrm{sec} / 100 \mathrm{~cm}$ で測定し, Morero の吸光係数を用い て見かけのミクロ構造の濃度をそれぞれ計算したのち， 検量線により正しい䀼度を求めた。

\section{3 網目間鎖数濃度の測定法}

網目間鎖数涱度を求める方法には膨潤法と応力ーひず み曲線より求める方法がある。膨潤法は Flory の式息に. 従い, 次式から鎖数㵝度が求为られる。

$$
\nu_{S}=\frac{V_{R}+\mu V_{R^{2}}+\ln \left(1-V_{R}\right)}{-V_{0}\left(V_{R}^{\frac{1}{3}}-\frac{2}{2}\right)}+\frac{2}{M}
$$

ขS：膨潤法による網目間鎖数濃度 $\left(\mathrm{mol} / \mathrm{cm}^{3}\right)$

$V_{R}$ ：膨潤ゴムに対する膨潤前ゴムの容積比率

$V_{0}$ ：膨潤溶媒の分子容

$M:$ 加硫前のゴムの分子量

$\mu:$ ポリマー溶媒間相互作用定数

本報では、溶媒としてベンゼンを用い, $20^{\circ} \mathrm{C} て ゙ 48$ 時間: 膨潤させた。膨潤前のゴムの容積として膨潤実駼中抽出 されたゴム容皘をもとの容積から差し引いた值を用い た。なお,ポリブタジェンの $\mu$ 值についてはベンゼン系で $0.39^{5)}, n$-デカン系で $0.54^{6)}$ となっているがどちらもハ 一オキサイド加硫物についてのデータである。そこで本 研究にあたりイオウ加硫物についての応力ーひずみ曲線. から網目間鎖数濃度を求め, 膨潤法のそれと比較するこ 
Table 2. $\mu$ value for cis-polybutadiene.

\begin{tabular}{c|c|c|c}
\hline \hline Sample & $V_{\boldsymbol{R}}$ & $2 m$ & $\mu$ \\
\hline A $1-1$ & 0.1925 & $1.82 \times 10^{-4}$ & 0.39 \\
A 2-1 & 0.2056 & $2.05 \times 10^{-4}$ & 0.38 \\
A 3-1 & 0.2004 & $1.82 \times 10^{-4}$ & 0.40 \\
A 4-1 & 0.1910 & $1.79 \times 10^{-4}$ & 0.38 \\
A 9-1 & 0.1693 & $1.35 \times 10^{-4}$ & 0.39 \\
B 1 & 0.1700 & $1.26 \times 10^{-4}$ & 0.40 \\
B 2 & 0.1770 & $1.44 \times 10^{-4}$ & 0.39 \\
\hline
\end{tabular}

A: Sulfur vulcanizate, B: Peroxide vulcanizate, $V_{R}$ : Swelling ratio (swelled for 48 hours at $20^{\circ} \mathrm{C}$ in benzene), $\nu_{m}$ : Cross-linking chain concentration ( $\mathrm{mol} /$ cc) calculated by stress-strain relation

とにより $\mu$ を求めた。すなうち, 島津製作所製オート グラフを用いて加硫ゴム試料の応力ーひずみ曲線を描き， 次式9)に徉って $\left(\alpha-1 / \alpha^{2}\right)$ と $f$ との関係をプロットし 直線部分の勾配から網目間鎖数浱度 $\nu_{m}$ を决定した。

$$
f=\nu_{m} R T\left(\alpha-\frac{1}{\alpha^{2}}\right)+f_{0}
$$

$f:$ 伸張度 $\alpha$ における応力

$\nu_{m}$ ：応力ーひずみ曲線法による網目間鎖数濃度

$R:$ 気体定数

$T:$ 絶対温度

$f_{0}$ : 補正応力

（2）式で求めた $\nu_{m} を \nu_{m}=\nu s$ として (1)式に代入す ることにより $\mu$ が得られる。 $\mu$ の算出結果を Table 2 に示した。 $V_{R} \succeq \mu$ との間には一般に $\mu=\mu_{0}+\beta V_{R}$ の 関係 ${ }^{13)}$ 方あり, 加硫度と之もに $\mu$ 注变化し, 変化の割合 浪溶媒より貧溶媒の場台汇大きい上されているが，必 ずしもそうでない場合もある。本研究ではデータが少な $く, V_{R}$ 変化の幅も狭いが， $V_{B}$ による $\mu$ の变化の傾向 は認められ-ま゙, 平均值 $\mu=0.39$ をとり網目間鎖数浱度 עs 它算出した。

\section{4 二重結合消費効率および橋かけ効率の算出法}

二重結合消費勃率 $f_{F}$ はシス，トランス，およびビ二 ルの各楧造浱度の和与斿ち全二重結合湍度の変化量 $\Delta F \mathrm{~mol}$ と分解パーオキサイド量 [RO·] mol あるいは結 合イオウ量 $\left[\mathrm{S}_{c}\right] \mathrm{mol}$ とから

$$
f_{P}=J F /[\mathrm{RO} \cdot], \text { あるい: } J F /\left[\mathrm{S}_{c}\right]
$$

として求められる。

パーオキサイドの分解量は Hummel らの方法10)によ り定量されるが，分解速度は媒体にあまり関係しない5) ので, Hummel らのデータ11)に基き分解したパーオキサ イドの濃度 [RO・] を求めた。イオウ系については亚硫 酸ナトリウム法12)で遊離イオウを測定し, 供試イオウ量 との差から結合イオウ量を求めた。

橋加勃率 $f_{c}$ は膨潤度測定より求めた網目間鎖数浱 度 עs とパーオキサイドの分解量 [RO·] あるいは結合
イオウ量 $\left[\mathrm{S}_{c}\right]$ 上から，

$$
\text { として求めた。 }
$$

$$
f_{c}=\nu_{S} /[\mathrm{RO} \cdot] \text {, あるい法 } /\left[\mathrm{S}_{c}\right]
$$

\section{5 実験結果}

ATR 法による加硫中における各ミクロ構造の変化流 Fig. 1 のとおりである。配合戍による吸収は加硫中変化 しないものと仮定し，配合剤による補正*1を行なったも のである。加硫が進むとともにイオウ加硫物あるいはパ 一オキサイド加硫物いずれもビニル結合の変化はほとえ ど認められないか，シス構造は減少し，一部はトランス 構造に異性化することがわかる。トランス構造も橋かけ に消費されるはずであるが，シス楧造より加硫速度が遟 く14)，また橋かけに消費されるとしても，その消費量よ りも多くシス構造がトランス構造に異性化していること になる。Fig. 2 はシス, トランス構造についてそれぞれ の初濃度に対する変化の割合をプロットしたもので，イ オウ系に比ベてハーオキサイド系ではシス裖度の減少が 大きい割にトランス濃度の增加は小さい。しかし,シス，

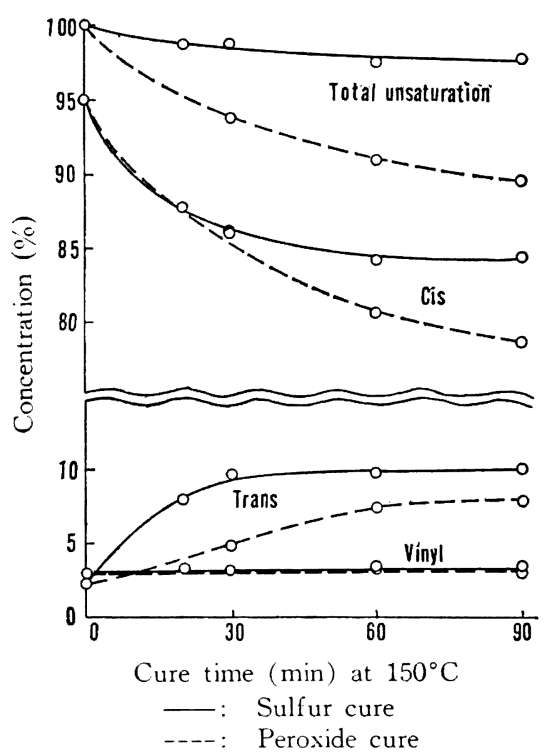

Fig. 1. Change of concentration of microstructure during vulcanization.

*1 配合剂の補正

原料ゴムの吸光度 $D_{A}$, 未加硫配合ゴムの吸光度 $D_{A B}$, 配台ゴム中ゴムの容稓を $A$, 配合郕の容皘を $B$ とする と配合ゴム中のゴムによる吸収は $D_{A} \times(A /(A+B))$, 配 合剂による吸收 $D_{B}=D_{A B}-D_{A} \times(A /(A+B))$, 加硫中こ の $D_{B}$ が変化しないと仮定すると, 加硫時間 $t$ の試料 の吸光度が $D t$ のとき, 補正吸光度 $D$ は次式により求 められる。

$$
D=\left(D_{t}-D_{B}\right) \frac{(A+B)}{A}
$$




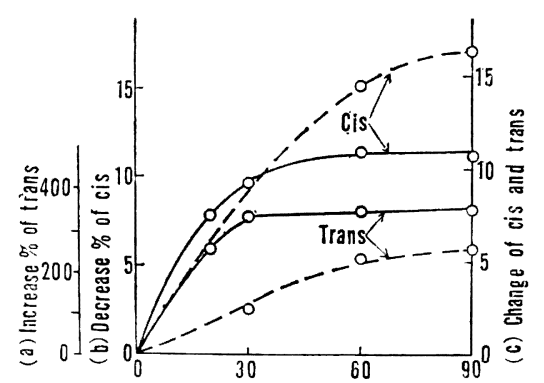

Cure time $(\mathrm{min})$ at $150^{\circ} \mathrm{C}$

$$
\text { - : Sulfur cure }
$$

Peroxide cure

${ }^{*} C_{0}$ : Initial cis-concentration, $C$ : cis-concentration of cured sample, $T_{0}$ : Initial trans-concentration, $T$ : trans-concentration
(a): $\quad\left\{\left(T-T_{0}\right) / T_{0}\right\} \times 100$
(b): $\quad\left\{\left(C_{0}-C\right) / C_{0}\right\} \times 100$
(c): $\left(T-T_{0}\right)$ or $\left(C_{0}-C\right)$

Fig. 2. Change of cis-, and trans-concentration during vulcanization.

トランスの相対值の变化（すなわち, 全二重結合浱度= 100 とした場合のシス,トランス䀼度变化) は Fig. 3 の とおりで,イオウ系の方がややトランス摆度が大きいが, イオウ系パーオキサイド系ともだいたい同じ濃度比で平 衡になるようである。

次に二重結合消費勃率の加硫時間に対する変化は Fig. 4 のとおりであり, イオウ加硫系では結合イオウ量の 0.5 1 倍に相当する二重結合しか消費されないが,ハー オキサイド加硫采では90分加硫で分解パーオキサイドの 約14倍に相当する二重結合が失われている。なお，ハーー オキサイドはポリマー中の老化防止尛や空気中の酸素あ るい他の不純物との反応によっても失われるので，こ れらの副反応のない条件で完全分解させた場合, 二重結 合消費勃率はさらに大きくなると考えられる。

一方,䁗潤法による網目間鎖数濃度の測定結果は Fig.

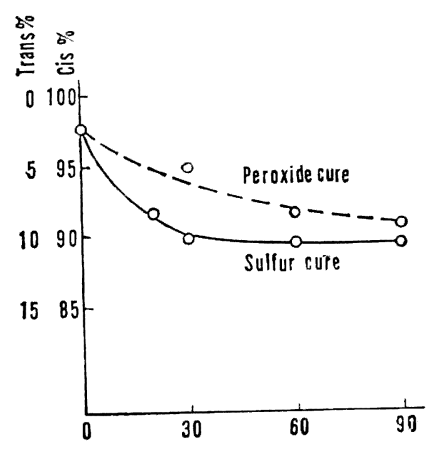

Cure time $(\mathrm{min})$ at $150^{\circ} \mathrm{C}$

Fig. 3. Change of cis-trans relative concentration.

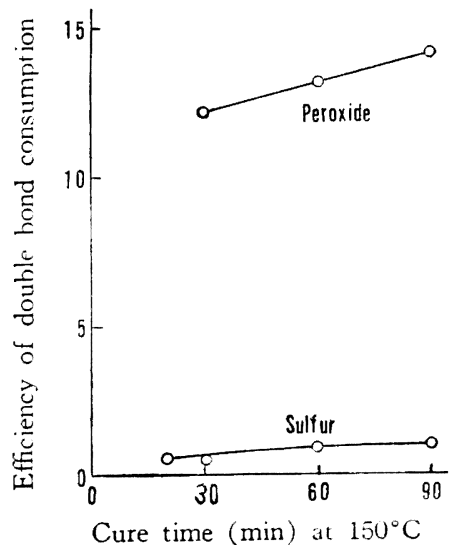

Fig. 4. Efficiency of double bond consumption.

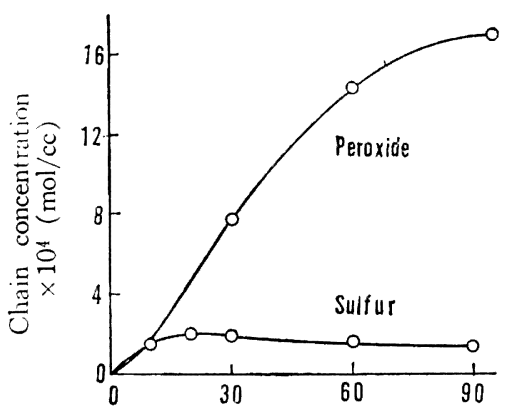

Cure time $(\mathrm{min})$ at $150^{\circ} \mathrm{C}$

Fig. 5. Change of cross chain concentration during vulcanization.

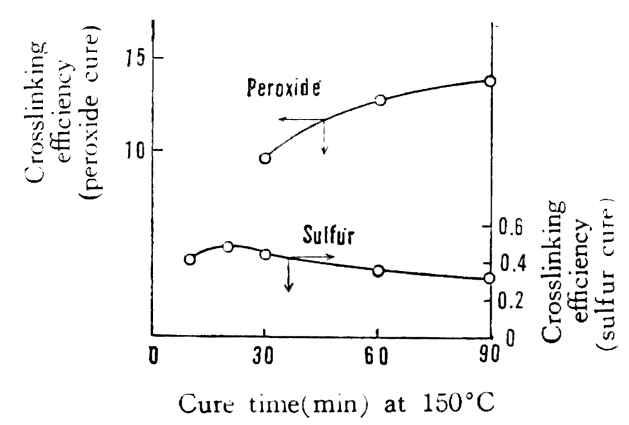

Fig. 6. Crosslinking efficiency.

5 のとおりで, パーオキサイド加硫系ではパーオキサイ ドの分解に伴い, 鎖数が増加するのに対し,イオウ加硫系 では鎖数濃度に最大值があり，このことは過加硫におい て橋かけ点の減少または主鎖の切断が起こっていること になる。橋かけ効率の計算結果は Fig. 6 のとおりで,

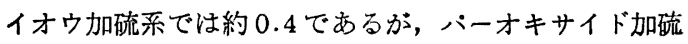
系では 90 分加硫で約 14 となっており, Table 3 のごと 
Table 3. Crosslinking efficiency of cis-polybutadiene.

\begin{tabular}{l|l|l}
\hline Vulcanization & Efficiency & \\
\hline $150^{\circ} \mathrm{C}, 90 \mathrm{~min}$ & 14 & $\nu /[\mathrm{RO} \cdot]$, this paper \\
$153^{\circ} \mathrm{C}, 70 \mathrm{~min}$ & $10.5^{6)}$ & $(\nu / 2) /[\mathrm{ROOR}]=\nu /[\mathrm{RO} \cdot]$ \\
$145^{\circ} \mathrm{C}, 8 \mathrm{hr}$ & $13^{5)}$ & $\nu / 2[\mathrm{ROOR}]-1=12$ \\
\hline
\end{tabular}

\section{く文献値 ${ }^{5), 6)}$ に近い值である。}

次に加硫度の異なる試料についての二重結合消費効率 と橋かけ効率との関係は Fig. 7 および Fig. 8 のとお りである。パーオキサイド加硫采について両効害がほほ 等しい関係にあり,両効萃とも10以上になることはシスー ボリブタジェンの橋かけが二重結台に対するラジカル付 加の連鎖反応によって進んでいるこ上を示している。付 加的連鎖反応では二重結合が一つ失われるごレに鎖が一 つ増加する。<smiles>C=CC(C)C(C)C(C)C(C)C(C)C(C)C(C)C</smiles>

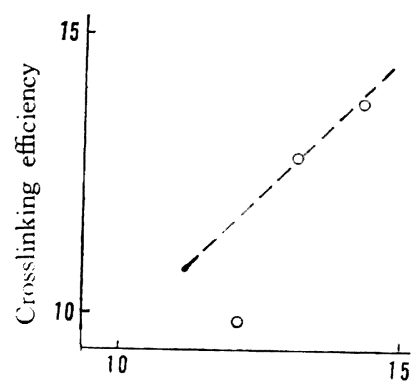

Efficiency of double bond consumption

Fig. 7. Relation between efficiency of double bond consumption and crosslinking efficiency in peroxide cure.

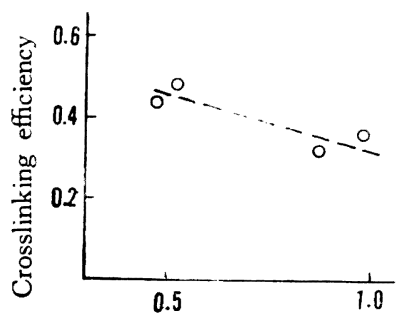

Efficiency of double bond consumption

Fig. 8. Relation between efficiency of double bond consumption and crosslinking efficiency in sulfur cure.

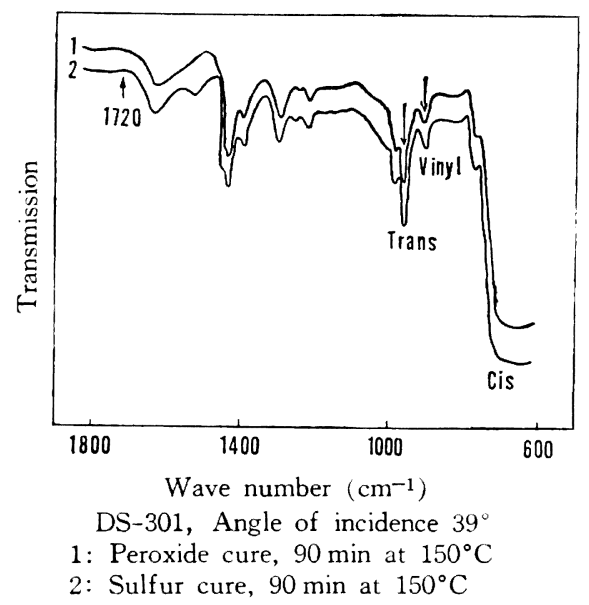

Fig. 9. ATR spectra of cured samples.

したがって二重結合消賣量と網目間鎖数濃度の生成量と が等しく両効率がー致することになる。

一方, イオウ加硫系では二重結合消費効率, 橋かけ効 率ともに 1 以下であり連鎖的反応が起こっている可能性 は小さいが，二重結合を消費せず $\alpha$ チレン基の水素の 置換による橋かけのみならず，二重結合への付加反応あ るいは分子内橋かけにより二重結合が消費されているこ とを示している。また,この場合,加硫時間が長くなると 網目間鎖数濃度の減少が認められるが，二重結合浱度の 変化は橋かけ点，あるいは主鎖の切断にも関係している ようである。しかし，これらについてはさらに検討する 必要がある。なお，プレス加硫中空気中の酸素により酸 化されカルボニル基が生成することも考えられるが, Fig. 9 のようにパーオキサイド加硫系, イオウ加硫系と も $1720 \mathrm{~cm}^{-1}$ におけるカルボニル基の吸収は認められな かった。

以上, ATR 法により加硫中におけるシスーボリブタジ エンのミクロ構造の变化の測定が可能であり，イオウ系 ならびにバーオキサイド采についてシス, トランス異性 化が認められ, さらにパーオキサイド加硫系で二重結合 消費量と橋かけ生成量とがほぼ比例して大きく, シスーボ リプタジェンのパーオキサイドによる加硫では二重結合 に刘与るラジカル付加の連鎖反応で橋かけが進むことを 認めた。

付 記: 本研究は昭和 40 年 4 月 4 日, 日本化学会第 18年会 (大阪)にて瀞演した。

\section{文献}

1) C. G. Moore, M. Porter: Rubber Chem. Technol., 36, 547 (1963)

2) B. A. Dogadkin, V. A. Shershnev: Rubber Chem. Technol., 35, 1 (1962) 
3）劍 実夫：ゴム協, 30, 364 (1957)；34, 197 (1961)

4) L. Bateman, C. G. Moore, G. W. Ross, M. Porter: Rubber Chem. Technol., 31, 1055, 1065, 1077, 1090 (1958)

5) Van der Hoff: IEC Prod. Res. Develop., 2, 273 (1963)

6) L. D. Loan: J. Appl. Polymer Sci., 7, 2259 (1963)

7）林 順之助, 古川淳二, 山下晋三：高化， 23，527 (1966)

8) P. J. Flory: J. Chem. Phys, , 18, 108 (1950)
9）古川淳二，小谷悌三，山下晋三：ざム協，34，162 (1961)

10) K. Hummel, G. Schlüter: Kaut. u. Gummi, 14, WT 269 (1961)

11) K. Hummel, W. Scheele, K. H. Hillmer: Kaut. u. Gummi, 14, WT 171 (1961)

12) JIS-K 6350, ASTM-D 297-55 T

13) G. Kraus: Rubber World, 135, 67 (1956)

14) W. A. Smith, J. M. Willis: Rubber Age, 87, $815(1960)$

\section{Quantitative Analysis of Microstructure of Rubber}

\section{Change of Microstructure in cis-Polybutadiene during Vulcanization}

By Junnosuke Hayashi*, Junji Furukawa** and Shinzo Yamashita**

Cis-trans isomerization and consumption of double bond in cis-polybutadiene during vulcanization were analyzed quantitatively by using the Attenuated Total Reflection Spectrometer (ATR). The result shows that cis-structure was isomerized by some curing agents to afford trans-structure. Decreasing amount of the double bond by peroxide was found to be much higher in comparison with sulfur-accelerator system. Crosslinking efficiency based on the concentration of decomposed peroxide has attained to about 10 . The evidence obtained supports the suggestion that peroxide vulcanization for cis-polybutadiene should proceed by radical transfer reaction to the double bond.

* Central Research Institute, Ube Industries, Ltd. (Ube, Yamaguchi)

** Department of Synthetic Chemistry, Faculty of Engineering, Kyoto University (Yoshida, Sakyo-ku, Kyoto) 


\title{
〔78〕アクリルアミドの転位アニオン重合
}

第 3 報 n-ブチルリチウムおよびフェニルマグネシウムブロマイドによる重合 (1965 年 11 月 1 日受理)

中山博之*・東村敏延* ・岡村誠三*

\begin{abstract}
要 旨 触媒に $n-\mathrm{BuLi}$, および $\mathrm{PhMgBr}$ を用いて, 重合条件によるポリマー構造の変化を検郡し, 前報”の sec-BuONa の場合の結果と比較した。n-BuLi を触媒に用いた場合には, 収率およびモノマー初源 度による転位重合物の割合の変化は, sec-BuONa の場合に比較して小さかった。すなわち, 錯合体生成能力 の大きい触媒を用いると, モノマー初源度および収率によるポリマー構造の変化は小さい。転位反応にはモノ マーが関与しないものとして, モノマー濃度掞よび収率によるポリマー棈造の変化を動力学的に考察した。触 媒として sec-BuONa を用いると溶媒の種類によって転位重合物の割合が変化したが, $n$-BuLi，および $\mathrm{Ph}$ $\mathrm{MgBr}$ 老用いた場合にはその変化が認められなかった。触媒の種類および触媒の種類によるポリマー椿造の変 化は，対イオンの錯合体生成能力の強い場合に転位重合しやすいものとして説明される。また， $n$-BuLi では 低温 $\left(40^{\circ} \mathrm{C}\right)$ におふいても重合が可能で, 低温ではビニル重合部分の多いポリマーが得られた。
\end{abstract}

\section{1.緒言}

アクリルアミドの転位重合はアルコキシド以外のアニ オン触媒でも進行する。すなわち,一般のアニオン触媒で ある $n-\mathrm{BuLi},{ }^{2)}$ Grignard 試薬, ${ }^{3)}$ 金属 $\mathrm{Na}^{4)}$ などに よっても進行することが報告されている。前報1に述べ たように, 触媒を一つに限った場合でも重合条件によっ てポリマーの構造が変化することから, 対イオンとモ, マーの極性基の相互作用がポリマーの構造を決める上に 重要であることが推定された。ゆえに, 触媒の種類によ るポリマー構造の変化を检討することは興味深い。

本報告ではアルコキシド以外にモノマーとの錯合体生 成能力が大きいと思われる触媒について, 重合条件によ るポリマー構造の変化を定量的に検討し, 前報1)の secBuONa を用いた結果と比較した。そのため,ここでは, $n-\mathrm{BuLi}$ とフェニルマグネシウムブロマイドを用いた。 得られた結果から, 転位重合の反応機構について考察を 行なった。

\section{2. 実験}

\section{1 試 薬}

\section{1.1 触媒の合成}

$n$-ブチルリチウム $(n-\mathrm{BuLi})$ : ベンゼン中にて臭化ブ チルとリチウムを反応させて合成した。

フェニルマゲネシムブロマイト (PhMgBr)：常法 によりエーテル中で臭化ベンゼンとマグネシウムから合 成し, エーテルをトルェンに置換して用いた。 ${ }^{6)}$

\section{1 .2 溶 媒}

トルェン・ピリジン・ジメチルホルムアミド (DMF) ・クロルベンゼン・ニトロベンゼンはすべて前報1) と同 悌に精製し，使用した。

* 京都大学工学部高分子化学教室 (京都市左京区吉田泉殿町)

\section{2. 操 作}

重合方法, 生成ポリマーの粘度数の測定㧍よびポリ マー組成の定量はすべて前報1) と同様に行なった。転位 重合の割合を表わすには前報と同様 $T$ 比を用いた。

\section{3. 結果および考察}

\section{$3.1 n$-BuLi による重合}

触媒活性が強くて均一な触媒である $n-\mathrm{BuLi}$ を用いて 生成ポリマーの性質に及ぼす重合条件の影響を検討し た。

\subsection{1 ポリマー収率の影響}

ポリマーの $T$ 比抢よび $\eta_{s p} / C$ に及ぼす収率の影響に ついて,トルェン中での重合結果を Fig. 1 に示した。収

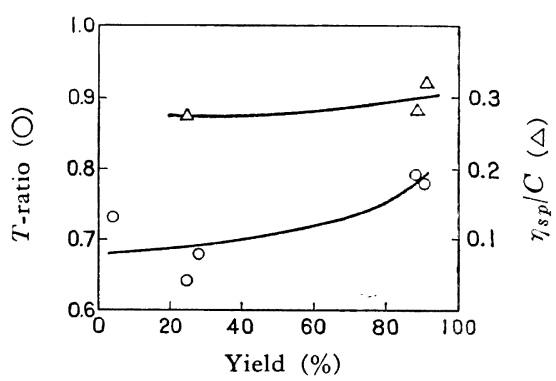

$[\mathrm{M}]_{0} 0.85 \mathrm{~mol} / l$, [BuLi] $0.020 \mathrm{~mol} / l$, Solvent: toluene, Temperature $100^{\circ} \mathrm{C}$

Fig. 1. Effect of polymer yield on the structure of polymer.

率の増加とともにポリマーの $T$ 比はわずかに増大する 傾向にあった。しかし, その程度は, 前報1) の sec$\mathrm{BuONa}$ の場合と比較して少なかった。また, ポリマー の $\eta_{s p} / C$ は収率によってほとんど変化しなかった。 
ピリジン中の重合における収率の影響を Fig. 2 に示 した。この場合にもポリマーの $T$ 比は重合後期に増大

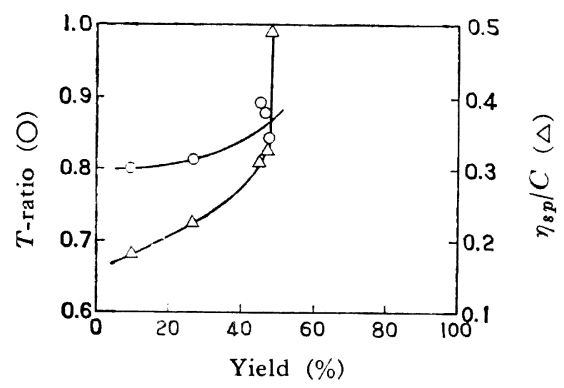

$[\mathrm{M}]_{0} 0.85 \mathrm{~mol} / l,[\mathrm{BuLi}]_{0} 0.030 \mathrm{~mol} / l$, Solvent: pyridine, Temperature $100^{\circ} \mathrm{C}$

Fig. 2. Effect of polymer yield on the structure of polymer.

する傾向にあった。また，ポリマーの $\eta_{s p} / C$ は収率の増 加とともに著しく增加する傾向にある。この系では長時 間重合させてもメタノール不溶性のポリマーの収率は $50 \%$ 以上にはならなかった。 $50 \%$ 付近では, 収率は上 がらなくとも, 重合時間とともに $\eta_{s p} / C$ は増加した。ゆ えにこの系では, トルェン中の場合と異なって, ポリマ ービうしの反応が起こりやすいものと考えられる。

\subsection{2 モノマー濃度の影響}

ポリマーの $T$ 比および $\eta_{s p} / C$ に及ぼすモノマー初濃 度の影響について，トルェン中での重合結果を Fig. 3 に示した。ここで, 收率はすべて 80 \%以上であった。 $T$

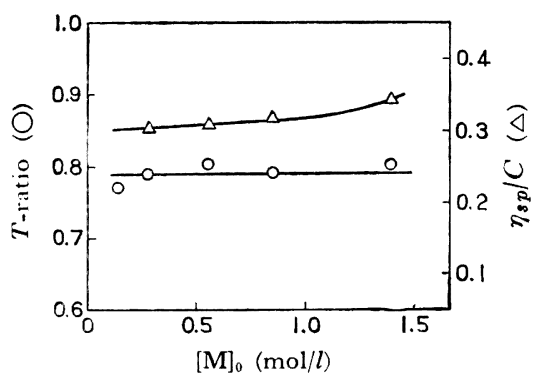

$[\text { BuLi }]_{0} 0.020 \mathrm{~mol} / l$, Solvent: toluene, Temperature $100^{\circ} \mathrm{C}$, Time $1 \mathrm{hr}$

Fig. 3 Effect of monomer concentration on the structure of polymer.

比および $\eta_{s p} / C$ 両者とも, モノマー初濃度 $\left([\mathrm{M}]_{0}\right)$ による 変化はほとんど認められなかった。この結果は, 前報1) の $\mathrm{sec}-\mathrm{BuONa}$ の場合にモノマー初浱度の増加に伴う $T$ 比の減少する結果と著しく異なっている。さきの収率に よる $T$ 比の変化も sec-BuONa よりも $n$-BuLi の場合 の方が少ないことを考えあわせると，重合系中に残存す
るモノマー浱度の $T$ 比に及ぼす影響が, $n$ - BuLi の場合 に小さいものと考えられる。

ピリジン中の重合におけるモノマー初濃度の影響を Fig. 4 に示した。ここで収率はモノマー濃度が 0.28

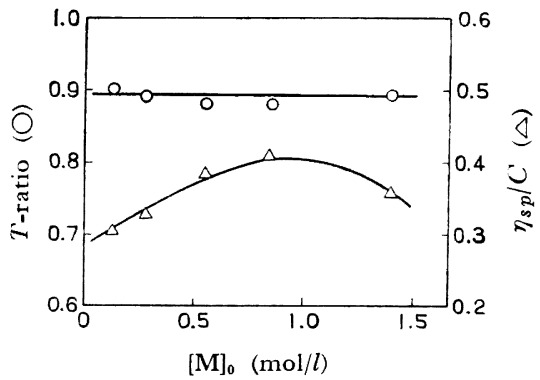

[BuLi] $0.040 \mathrm{~mol} / l$, Solvent : pyridine, Temperature $100^{\circ} \mathrm{C}$, Time $1 \mathrm{hr}$

Fig. 4. Effect of monomer concentration on the structure of polymer.

$\mathrm{mol} / l$ のとき $(54 \%)$ を除いて他はすべて約 $80 \%$ であっ た。ポリマーの $T$ 比はトルェン中の場合と同様に, モノ マー初濃度によってほとんど変化せず, $\eta_{s p} / C$ の変化も 小さかった。

\subsection{3 触媒濃度の影鉝}

ポリマーの $T$ 比および $\eta_{s p} / C$ に及ぼす $n-\mathrm{BuLi}$ 初濃 度の影響について, トルェン中での重合結果を Fig. 5

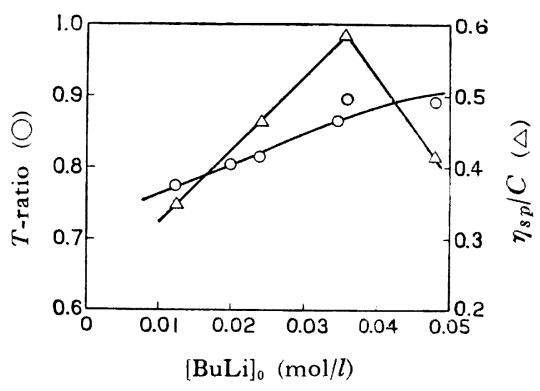

$[\mathrm{M}]_{0} 1.41 \mathrm{~mol} / l$, Solvent : toluene, Temperature $100^{\circ} \mathrm{C}$, Time $2 \mathrm{hr}$

Fig. 5. Effect of catalyst concentration on the structure of polymer.

に示した。触媒濃度の増加とともに, ポリマーの $T$ 比は 増加した。

また, 触媒初濃度の変化によってポリマーの $\eta_{s p} / C$ は sec-BuONa の場合よりもかなり大きく変化する。実験 結果は少ないが, 触媒初濃度約 $0.035 \mathrm{~mol} / l$ のところ(モ ノマー量の約 $1 / 40)$ で最大值を持つようである。この結 果は, 谷ら 2)の触媒量はモノマーとのモル比 1/30 程度が 
良好であるといら結果に類似している。

\subsection{4 重合温度の影響}

重合温度による収率, ポリマーの $T$ 比および $\eta_{s p} / C$ の変化について, トルェン溶媒中の結果を Fig. 6 に示 した。n-BuLi は活性が大きいので, sec-BuONa と比

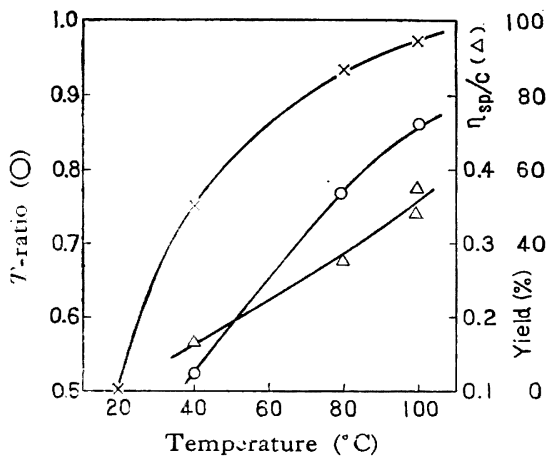

[BuLi] $]_{\curvearrowleft} 0.034 \mathrm{~mol} / l\left(80\right.$ and $\left.100^{\circ} \mathrm{C}\right)$ $0.024 \mathrm{~mol} / l\left(20\right.$ and $40^{\circ} \mathrm{C}$ )

$[\mathrm{M}]_{0} 1.41 \mathrm{~mol} / l\left(80\right.$ and $\left.100^{\circ} \mathrm{C}\right), 2.82 \mathrm{~mol} / l(20$ and $\left.40^{\circ} \mathrm{C}\right)$, Solvent : toluene, Time $2 \mathrm{hr}\left(80\right.$ and $\left.100^{\circ} \mathrm{C}\right)$, $60 \mathrm{hr}\left(40^{\circ} \mathrm{C}\right), 100 \mathrm{hr}\left(20^{\circ} \mathrm{C}\right)$

Fig. 6. Effect of polymerization temperature on the structure of polymer.

較してかなり低温でも重合した。たとえば，モノマーが 溶媒にほとんど溶解していない状態である, $20^{\circ} \mathrm{C}$ (モ) マー溶解量 $0.01 \mathrm{~mol} / l)$ 亿扔いては 100 時間反応させて もポリマーは得られなかったが, $40^{\circ} \mathrm{C}$ (モ)マー溶解量 $0.04 \mathrm{~mol}(l)$ では反応速度は遅いが，ポリマーを得た。重 合温度による $T$ 比の変化を見ると, 重合温度の低下とと もに，T比は急激に減少した。Fig. 1 に示したように， $n-B u L i$ 触媒では収率による $T$ 比の変化は小さいから, Fig. 6 の結果は重合温度の $T$ 比に及ぼす影響を示して いるものと考えられる。すなわち,ビニル重合よりも転
位重台に要する活性化エネルギーの方が大きく, Fig. 6 からその差は約 $7 \mathrm{kcal} / \mathrm{mol}$ であった。また，ポリマー の $\eta_{s p} / C$ も重合温度の増加とともに増大した。これは, $s e c-\mathrm{BuONa}$ 触媒での 重合温度の 影響で述べたように, 重合温度の増大とともに，ポリマーおよびオリゴマー間 の反応が起こるためだと考えられる。

\subsection{5 重合溶媒の影響}

重合溶媒の影響を Table 1 にまとめた。極性溶媒で は, メタノール不溶部の収率が小さいので, モノマーの 変化を調べるために, メタノール不溶部の他にメタノー ル可溶でアセトン不溶部分の収率および, 残存モノマー 濃度から求めたモノマーの変化率も記した。ここで, 残 存モノマー濃度はガスクロマトグラフィーにより測定し た。測定条件はカラムにポリェチレングリコールを用い, カラ山温度 $180^{\circ} \mathrm{C}, \mathrm{H}_{2}$ 流速 $70 \mathrm{cc} / \mathrm{min}$ で, 測定誤差は $\pm 3 \%$ であった。

Table 1 に示したように, アセトン不溶部の IR ス ペクトルはメタノール不溶部と同様であり, $\eta_{s p} / C$ の

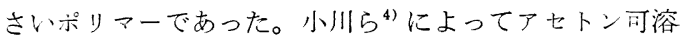
性の生成物は Dimer であることが觙めら机ており，し たがって生成ポリマーとモノマー消費量の差は Dimer に変化したモノマー量と考えられる。しかし，ポリマー の $T$ 比は, メタノール不溶部, アセトン不溶部とも, 溶 媒によって差異は認められなかった。また, メタノール 不溶部の $\eta_{s p} / C$ はトルェン・ピリジン中においては sec$\mathrm{BuONa}$ を用いた場合よりも大であった。

\section{$3.2 \mathrm{PhMgBr}$ による重合}

均一触媒で, $n-\mathrm{BuLi}$ よりも活性の小さい $\mathrm{PhMgBr}$ を用いて重合を行なった。ピリジン溶媒中で得たポリマ 一の $T$ 比执よび $\eta_{s p} / C$ と収率の関係を Fig. 7 に示し た。メタノール不溶部の収率は $40 \%$ しか上がらなかっ たが，後述するように残りのモノマーはほとんどアセト ン不溶部の低分子量のポリマーになっていた。 $T$ 比は 収率の変化によってほとんど 変化しなかった。しかし，

Table 1. Effect of solvent on polymerization by $n$-BuLi.

\begin{tabular}{c|c|c|c|c|c|c|c|c|c|c}
\hline No. & Solvent & $\begin{array}{c}\text { Time } \\
\text { (hr) }\end{array}$ & $\begin{array}{c}\text { Yield of } \\
\text { methanol } \\
\text { insoluble } \\
\text { part(\%) }\end{array}$ & $\begin{array}{c}\text { Yield of } \\
\text { acetone } \\
\text { insoluble } \\
\text { part(\%) }\end{array}$ & $\begin{array}{c}\text { Yield } \\
\text { of total } \\
\text { polymer } \\
(\%)\end{array}$ & $\begin{array}{c}\text { Monomer } \\
\text { conver- } \\
\text { sion* } \\
(\%)\end{array}$ & $\begin{array}{c}\eta_{s p} / C \text { of } \\
\text { methanol } \\
\text { insoluble } \\
\text { part }\end{array}$ & $\begin{array}{c}T \text { - ratio of } \\
\text { acetone } \\
\text { insoluble } \\
\text { part }\end{array}$ & $\begin{array}{c}\eta_{s p} / C \text { of } \\
\text { acetone } \\
\text { insoluble } \\
\text { part }\end{array}$ & $\begin{array}{c}T \text {-ratio of } \\
\text { acetone } \\
\text { insoluble } \\
\text { part }\end{array}$ \\
\hline 196 & Toluene & 1 & 98 & - & - & - & 0.34 & 0.80 & - & - \\
150 & Pyridine & 2 & 36 & 19 & 55 & 85 & - & 0.80 & - & - \\
151 & Pyridine & 5 & 50 & 6 & 56 & 84 & 0.49 & 0.80 & 0.06 & 0.82 \\
148 & DMF & 2 & trace & 28 & 28 & 55 & - & - & 0.06 & 0.80 \\
149 & DMF & 10 & 5 & 37 & 37 & 83 & - & 0.83 & - & 0.75 \\
\hline
\end{tabular}

$[\mathrm{M}]_{0} 1.41 \mathrm{~mol} / l, \quad[n-\mathrm{BuLi}]_{0} \quad 0.024 \mathrm{~mol} / l, \quad$ Temperature $100^{\circ} \mathrm{C}$

* This value was determined by gas chromatography. 
Table 2. Effect of solvent on polymerization by $\mathrm{PhMgBr}$.

\begin{tabular}{|c|c|c|c|c|c|c|c|c|c|c|}
\hline No. & Solvent & $\underset{(\mathrm{hr})}{\text { Time }}$ & $\begin{array}{l}\text { Yield of } \\
\text { methanol } \\
\text { insoluble } \\
\text { part }(\%)\end{array}$ & $\begin{array}{l}\text { Yield of } \\
\text { acetone } \\
\text { insoluble } \\
\text { part }(\%)\end{array}$ & $\begin{array}{l}\text { Yield } \\
\text { of total } \\
\text { polymer } \\
(\%)\end{array}$ & $\begin{array}{l}\text { Monomer } \\
\text { conver- } \\
\text { sion* } \\
(\%)\end{array}$ & $\begin{array}{c}\eta_{s p} / C \text { of } \\
\text { methanol } \\
\text { insoluble } \\
\text { part }\end{array}$ & $\begin{array}{c}T \text {-ratio of } \\
\text { methanol } \\
\text { insoluble } \\
\text { part }\end{array}$ & $\begin{array}{c}\eta_{s p} / C \text { of } \\
\text { acetone } \\
\text { insoluble } \\
\text { part }\end{array}$ & $\begin{array}{c}T \text {-ratio of } \\
\text { acetone } \\
\text { insoluble } \\
\text { part }\end{array}$ \\
\hline 152 & Toluene & 1 & 61 & 12 & 73 & 87 & 1.09 & 0.87 & - & 0.78 \\
\hline 153 & Toluene & 5 & 80 & 13 & 93 & 100 & 0.89 & 0.89 & 0.07 & 0.72 \\
\hline 182 & Pyridine & 1 & 32 & 64 & 96 & 100 & 0.11 & 0.88 & 0.06 & - \\
\hline 154 & DMF & 2.5 & 10 & 39 & +9 & 77 & 0.08 & 0.92 & - & 0.74 \\
\hline 155 & DMF & 5 & 14 & 37 & 51 & 76 & 0.10 & 0.87 & 0.06 & 0.71 \\
\hline
\end{tabular}

$[\mathrm{M}]_{0} 1.41 \mathrm{~mol} / l, \quad[\mathrm{PhMgBr}]_{0} 0.10 \mathrm{~mol} / l$, Temperature $100^{\circ} \mathrm{C}$

* This value was determined by gas chromatography.

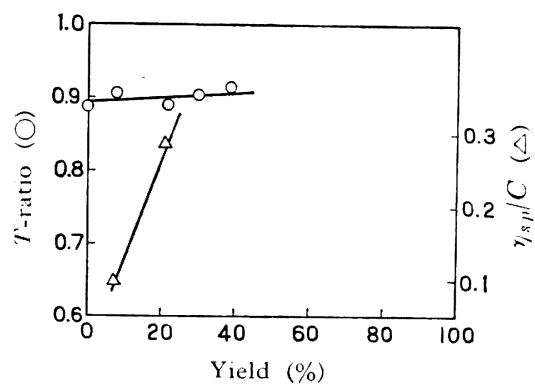

$[\mathrm{M}]_{0} 0.85 \mathrm{~mol} / l, \quad[\mathrm{PhMgBr}]_{0} 0.060 \mathrm{~mol} / l$ Solvent: pyridine, Temperature $100^{\circ} \mathrm{C}$

Fig. 7. Effect of polymer yield on the structure of polymer.

$\eta_{s p} / C$ は収率の増大とともに增大する傾向にあるが, 収 率が 30 および $40 \%$ の上ころでは，ギ酸に不溶のポリ マーが得られ， $\eta_{s p} / C$ は求められなかった。

重合溶媒の影響を Table 2 にましめた。 $n$-BuLi を触 媒に用いた場合上同様に，極性溶媒中ではメタノール不 溶部が減少し，アセトン不溶部が増加した。メタノール 不浴部の $T$ 比は溶媒によってあまり差は認められず, $n$ BuLi の場合よりも大きかった。トルェン中においいて特 に大きい $\eta_{s p} / C$ のポリマーが高收率で得られたが，ピリ ジンおよび DMF 中では $r_{s p} / C$ はきわめて小さかった。

\section{4. 考察}

前報1)および本報告で述べてきたように，転位重台の 割合は種々の重合条件によって変化する。この変化を説 明するためには，前報”において述べたように，モノ、 一浱度と対イオンの作用の二つの因子が重要だと考えら れる。この点に関して以下考察を行なった。

\section{1 モノマー濃度}

重合率，モノマー初浱度による重合型式の割合の変化 老,モノマー濃度を変数として動力学的に説明すること
を試みた。カルバニオンの反応過程とし下，(1)〜 (3) 式 の素反応を考えることができる。すなわち，(1) 式はカ ルバニオンがモノマーの二重結合に付加するビニル重合<smiles>NC(=O)CCC(CC(C=O)C(N)=O)C(N)=O</smiles><smiles>[CH]CCCC(=O)N[O-]</smiles>

$$
\begin{aligned}
& \underset{\mathrm{CONH}_{2}}{\mathrm{CH}^{\ominus}}+\underset{\mathrm{CHNH}_{2}}{\mathrm{CH}_{2}=}
\end{aligned}
$$

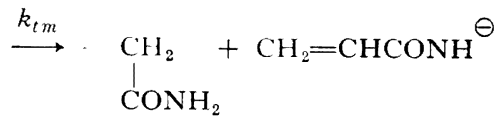

の生長反応である。また，(2) 式はプロトンが分子内転 位してカルバニオンが窒素アニオンになる転位反応であ り，(3) 式はカルバニオンがモノマーのプロトンを引抜 いて，新たに空素アニオンのできる分子間転位反応 (モ ノマー移動反応) である。

転位重合物とビニル重合物との比は，（1）式のビニル 重合成長反応と (2) およぴ (3) 式の窒素アニオンへの転 位反忘との速度比として表わせる。ゆえに，モノマー濃 度 [M] のときに生成されるポリマーの転位重合の割合 [T] は (4) 式で与えられる。ここでは, $\left[\mathrm{C}^{-}\right]$カルバニナ

$$
\begin{aligned}
T & =\frac{k_{t}\left[\mathrm{C}^{-}\right]+k_{t m}[\mathrm{M}]\left[\mathrm{C}^{-}\right]}{k_{t}\left[\mathrm{C}^{-}\right]+k_{t m}[\mathrm{M}]\left[\mathrm{C}^{-}\right]+k_{p 1}[\mathrm{M}]\left[\mathrm{C}^{-}\right]} \\
& =\frac{k_{\iota}+k_{t m}[\mathrm{M}]}{k_{t}+\left(k_{t m}+k_{p 1}\right)[\mathrm{M}]}
\end{aligned}
$$


3）劍 実夫：ゴム協, 30, 364 (1957)；34, 197 (1961)

4) L. Bateman, C. G. Moore, G. W. Ross, M. Porter: Rubber Chem. Technol., 31, 1055, 1065, 1077, 1090 (1958)

5) Van der Hoff: IEC Prod. Res. Develop., 2, 273 (1963)

6) L. D. Loan: J. Appl. Polymer Sci., 7, 2259 (1963)

7）林 順之助, 古川淳二, 山下晋三：高化， 23，527 (1966)

8) P. J. Flory: J. Chem. Phys, , 18, 108 (1950)
9）古川淳二，小谷悌三，山下晋三：ざム協，34，162 (1961)

10) K. Hummel, G. Schlüter: Kaut. u. Gummi, 14, WT 269 (1961)

11) K. Hummel, W. Scheele, K. H. Hillmer: Kaut. u. Gummi, 14, WT 171 (1961)

12) JIS-K 6350, ASTM-D 297-55 T

13) G. Kraus: Rubber World, 135, 67 (1956)

14) W. A. Smith, J. M. Willis: Rubber Age, 87, $815(1960)$

\section{Quantitative Analysis of Microstructure of Rubber}

\section{Change of Microstructure in cis-Polybutadiene during Vulcanization}

By Junnosuke Hayashi*, Junji Furukawa** and Shinzo Yamashita**

Cis-trans isomerization and consumption of double bond in cis-polybutadiene during vulcanization were analyzed quantitatively by using the Attenuated Total Reflection Spectrometer (ATR). The result shows that cis-structure was isomerized by some curing agents to afford trans-structure. Decreasing amount of the double bond by peroxide was found to be much higher in comparison with sulfur-accelerator system. Crosslinking efficiency based on the concentration of decomposed peroxide has attained to about 10 . The evidence obtained supports the suggestion that peroxide vulcanization for cis-polybutadiene should proceed by radical transfer reaction to the double bond.

* Central Research Institute, Ube Industries, Ltd. (Ube, Yamaguchi)

** Department of Synthetic Chemistry, Faculty of Engineering, Kyoto University (Yoshida, Sakyo-ku, Kyoto) 